\title{
Factores asociados a actitudes sobre la sexualidad en la vejez en Medellín, Colombia ${ }^{1}$
}

\section{Factors associated with attitudes about sexuality in old age in Medellin, Colombia}

Recibido: 06 de julio de 2016 - Revisado: 24 de noviembre de 2016 - Aceptado: 07 de marzo de 2017.

Edgardo Javier Ramos Caballero ${ }^{2}$

Estela Melguizo Herrera ${ }^{3}$

\section{Resumen}

Se considera que los adultos mayores experimentan una regresión de todas sus funciones fisiológicas, como es el caso del disfrute de la sex lidad, perc la realidad muestra que las personas nacen y mueren sienc sexuadas. com nidad en su concepción errada, considera esta conducta como in $\mathrm{ct}_{1} \quad 4$. Para conocer los factores sociodemográficos asociados a las actitudes de los a ultr, l. . ${ }^{\prime}$ res ante la sexualidad, se desarrolló mediante la aplicación de ncuesta, n estudio descriptivo y analítico, no experimental de corte transve al, en mayores de 18 años. Existen actitudes prejuiciosas en relación con la sexu. Jad an el adult $\lrcorner$ mayor las cuales se acentúan mientras las personas tiener nayor eda La eaun...ón a la comunidad podría corregir algunos de estos prejuici $\mathrm{s}$.

Palabras clave Actitudes, sex alidad, ancianos y 1 juicios.

\begin{abstract}
It is col 'ered th. older adults experience a regression of all their physiological fu. tions, s is the ca. of the enjoyment of sexuality, but reality shows that people are born $1 d$. ning sexed. The community in its misconception, considers this behavior as una ptable. In order to know the sociodemographic factors associated with the attitudes slder adults before sexuality, it was developed through the application of a survey, a descriptive and analytical study, non-experimental of cross-section, in people over 18 years of age. There are prejudicial attitudes in relation to sexuality in the elderly, which are accentuated while people are older. Community education could correct some of these prejudices.
\end{abstract}

Keywords

Attitudes, sexuality, elders and prejudice.

\footnotetext{
${ }^{1}$ Artículo de revisión.

${ }^{2}$ Enfermero, Magister en Salud Pública. Doctorando en Ciencias Biomédicas del IUNIR. Docente Asociado de la Corporación Universitaria Adventista. Medellín, Colombia. Correo electrónico: ejramos@unac.edu. co. ORCID: https://orcid.org/00000001-8545-5503.

${ }^{3}$ Enfermera, Doctora en enfermería; Docente titular Facultad de Enfermería de la Universidad de Cartagena, Cartagena-Colombia, emelguizoh@ unicartagena.edu.co. ORCID: https:// orcid.org/0000-0002-8087-9718

Para citar este artículo use: Ramos, E., y Melguizo, E. (2017). Factores asociados a actitudes sobre la sexualidad en la vejez en Medellín, Colombia Civilizar Ciencias Sociales y Humanas, 17(33), 267-276.
} 